\title{
Exploring the Corporate Governance in Lloyd's and the Co-operative Bank: the Role of the Board
}

\author{
Adel Ahmed* \\ Liverpool Hope University, Liverpool Hope Business School, Hope Park, Liverpool \\ *Corresponding author: ahmeda@hope.ac.uk \\ Received March 19, 2015; Revised March 29, 2015; Accepted April 08, 2015
}

\begin{abstract}
Corporate Governance is a complex process through which the companies are directed and controlled. The purpose of corporate governance is to facilitate effective, entrepreneurial and prudent management that can deliver the long-term success of the company. Moreover the overall success and failure of the banking system depends upon the corporate governance principles and procedures applied in the banks. There are various guidelines which together make up the combine code for the corporate governance policies in the bank. The fact that the corporate governance is different in financial sectors than that of the non-financial sectors is because that the financial firms pose greater risk to the economy than that of the non-financial firms. This study aims to present the corporate governance principles and policies in the banking organisations in UK with special emphasis on the role of the board in these banks. For this purpose the two banks selected as a case study are the Lloyd's bank and the Cooperative bank. The role and responsibilities of the board and the committees are explored and discussed in this research.
\end{abstract}

Keywords: corporate governance in banking, the role of the board in financial sectors, the basel committee on banking supervision

Cite This Article: Adel Ahmed, "Exploring the Corporate Governance in Lloyd's and the Co-operative Bank: the Role of the Board." Journal of Business and Management Sciences, vol. 3, no. 1 (2015): 6-19. doi: 10.12691/jbms-3-1-2.

\section{Introduction}

\subsection{Background of the Study}

Corporate Governance principles and policies in the banking sector have attracted many scholars and researchers because of its importance and the key role it plays in the banking sector. In the implementation of the sound corporate governance principles in the banks the directors and the board play a very important role. The responsibilities assigned to the board for the management and smooth running of the banks determines the future of the bank. The directors are held liable for the setting the objectives of the bank, provide means to achieve those objectives, overseeing the risks posed with these objectives and overall management of the team in the bank. The study of the corporate governance of banks specifically in today's world is highly crucial element because in past many banks have failed due to inefficient practices of corporate governance policies. Recent scandals in the financial sector have brought corporate governance at the forefront of academic and supervisory attention. Banks' versatile role in the economic system has caught regulatory and supervisory interest around the world in an effort to inspire high quality corporate governance standards. Weak and ineffective corporate governance mechanisms in banks are pointed out as the main factors contributing to the recent financial crisis. The role of the banks is multifaceted and pivotal in the economic system and that's why has attracted much regulatory attention (Egoraki et al, 2009).There is no doubt in the fact that bank plays very vital role in the economy of the country. The overall success and failure of the economy of the country depends on the banks. Corporate governance in banks differs from the standard for other non-financial companies (Llewellyn, 2002), Cincanelli and ReyesGonzalez, 2000), Gup, 2007),Adams and Mehran 2003).

\subsection{Significance of the Study}

In the success and survival of the bank, corporate governance play a very vital role. The proper implementation of the policies of corporate governance leads towards the success of the banking industry. For the implementation of the corporate governance policies and principles the role of the board in the bank is very crucial. The board in the bank plays a very vital role in the success or failure of the bank's corporate governance policies. There has been a long debate about the corporate governance structures and principles and how sound corporate governance system can be achieved in a Banks. The size and composition of the board of directors constitute of the most essential corporate governance themes and have caught the attention of academics and regulators alike Egoraki et al (2009). 
The corporate governance of bank is a complex framework. This governance framework includes a bank's stockholders, its managers and other employees, and the board of directors. The operation of Banks is under a unique system of public oversight in the form of bank supervisors and a comprehensive body of banking laws and regulations. The interaction between all of these elements determines how well the performance of a bank will satisfy the desires of its stockholders, while also complying with public objectives. For investors and regulators, this bank corporate governance framework is thus of critical importance in a bank's success and its daily operations. While governance by bank stockholders and directors has always been viewed as important, this topic has drawn increased attention in recent years (Spong and Sullivan 2007). The concept of corporate governance is important for every firm whether financial or non financial or in every country whether developed or underdeveloped. Depositors, shareholders and regulators are concerned with the robustness of corporate governance mechanisms. The added regulatory dimension makes the analysis of corporate governance of banking firms more complex than in non-financial firms.

\subsection{Organisation of the Study}

The first section of the paper review the concept of corporate governance in the banks. There are various researchers and scholars who have explored the concept of corporate governance in banks in terms of its principles and policies that are needed by the bank in order to fulfil the corporate governance code. The concept of corporate governance is very difficult to understand and thus have gained much attention in today's world. The different definitions and discussions carried out by the researchers in this paper gives much more understanding of the rules and policies of the corporate governance in banking firms. Because of the importance of corporate governance in a bank the Basel committee has been organized and publish time to time different reports for guiding the banks in terms of the corporate governance issues. The definition of corporate governance given by the Basel committee is the relationship between a company's management, its board; shareholders and other stake holders and also it the means of setting the objectives of the company and achieving those objectives. Many other scholars including Shleifer and Vishny (1997), Grundmann and Mulbert (2000) and Levine (2004) discuss different concepts of the corporate governance of the banks and the relationship between the board of the bank with its shareholders and other stake holders.

The second section of the paper deals with the basics of corporate governance in the financial institutions and also gives us the answer of a question that is corporate governance different in the financial firms than the non financial firms? There is no doubt in the fact that the basics of every financial institution or firm lies in the corporate governance tools and techniques. Good governance leads to prosperity of the industry or firm and poor Governance leads to poor performance of the firm and effect the economy as a whole. Banks are very critical elements of the economy. However the questions that was addressed that is corporate governance system is same for all industry types is discussed in this section and given by the Adam and Mehran (2003) that corporate governance structure in the non financial firms are not suitable for the banking and other financial firms. Later in this section Eatwell and Taylor (2000) discussed that the corporate governance principles implemented in the banking and financial firms are not appropriate in the non financial firms and the reason lies in the fact is that financial firms and banks pose greater risk to the economy. Also, banks are subject to special regulations and supervision by state agencies (monitoring activities of the bank are therefore mirrored); supervision of banks is also exercised by the purchasers of securities issued by banks and depositors ("market discipline", "private monitoring"). The bankruptcy of a bank raises social costs, which does not happen in the case of other kinds of entities' collapse; this affects the behaviour of other banks and regulators. The relationship between the bank and its clients has a fiduciary relationships raising additional relationships and agency costs and problem principal-agent is more complex in banks, among others due to the asymmetry of information not only between owners and managers, but also between owners, borrowers, depositors, managers and supervisors. Therefore the success or failure of the corporate governance of banks leads to the success or failure of the whole economy of the country.

The third section of the review gives us the answer of the question after discussing the various definitions and concepts of corporate governance issues in a bank there is a need to discuss what is the best practice guide for the corporate governance of banks? The answer to this question is discussed here that the Basel committee gives the guidance for the banks in terms of their corporate governance issues and problems. The Basel Committee on Banking Supervision provides a forum for regular cooperation on banking supervisory matters. Its objective is to enhance understanding of key supervisory issues and improve the quality of banking supervision worldwide (Toniolo and Clement(2005); Borio et all (2008); Lefort(2009); James(2012))The Basel committee publish time to time reports and papers to ensure sound corporate governance principles and processes in every bank. The Basel committee has recognized the importance of the role of the banks in an economy and the different failures that originate from the inefficient and poor management of the corporate governance and the need for safeguard for the interests of the shareholders and other stake holders including super visors, Governments and depositors. The Basel committee for banking regulation gives guidance on all the corporate governance issue that arise in the banking organisation in day to day running of the business affairs in the bank. The different concepts and rules discussed by the Basel committee include corporate values and code of conduct, corporate strategy for overall success of the enterprise, the assignment if the responsibilities and authorities in the bank, the mechanisms of interaction between the board and the management, internal control systems and audit functions and appropriate information flow to the public. Based on these principles the banking organizations are required to follow this best practice guide in order to exercise the sound corporate governance principles and procedures.

The fourth section of the review explains what is the role of the board of directors in establishing the corporate governance policies in the bank? Board of directors have 
very vital role in the corporate governance of a bank. The key responsibilities that the board have in the bank are given by Spong and Sullivan (2007) are hiring, overseeing and management of the team, setting the objectives of the firm participating in various important decisions of the firm, The code of the best practice of corporate governance cannot be implemented in the bank without the board of directors. The board of directors act as the means for setting the corporate governance principles and procedures in the bank. That's why the role of the board in a bank has much importance not just in the implementation of the corporate governance policies but also in the overall success and failure of the bank itself.

Among all the responsibilities and the roles of the board in the bank mention above one of the very important element in the corporate governance of a bank is the ability of the bank to manage its risk. There are many examples of banks that have failed because of the improper management of risks within that specific bank in past. Risk management is complicated and time consuming process and deserves much more attention. In risk management again the role of the board play an important part. The role of the board is setting the tools and practices for effective risk management in the bank. Various scholars have discussed the need for the risk management in the bank Pyle (1997), Al-Tamimi and AlMazrooei (2007), Sensarma and Jayadev (2009) discussed the definitions of risk management and the importance of risk management in the bank. Further based on their research it has been find out that the commercial bank faces five types of risk which are credit risk, interest rate risk, liquidity risk, solvency risk, and operational risk. However to cope effectively and efficiently in the management of risk in the bank the seven steps given by Dedman and Robert-Tissot(2001) are very important to analyse.

The last section which deal with case study as it is the theme of the overall research is about the corporate governance in Lloyd's bank and in the Co-operative bank. How does the corporate governance works in both banks and what role the board of directors play in these banks in setting the corporate governance policies? The discussion is made on the various corporate governance policies that are practicing in the Lloyd's and Co-operative bank. The selection of these banks is because that the Lloyd's bank is commercial bank while the Co-operative bank works more on the ethical side. To discuss the corporate governance issues in both these banks and the role of the board in these banks gives us the proper answer of the questions and the objective of the overall research.

\section{Literature Review}

\subsection{Corporate Governance}

There has been great attention given to the corporate governance in various sectors. The success of any firm depends on its corporate governance structure and the way in which it is been implemented. As corporate governance cover the mechanisms, processes and relations by which corporations are controlled and directed. Corporate Governance recognise the distribution of rights and responsibilities among different stakeholders in the organisation include the board of directors, managers, shareholders, creditors, auditors, regulators, and other stakeholders and includes the rules and procedures for making decisions in business concerns. Corporate governance includes the processes through which corporations' objectives are set and pursued in the context of the social, regulatory and market environment (FRC, 2014). Governance mechanisms include monitoring the actions, policies and decisions of corporations and their agents. Corporate governance practices are affected by attempts to align the interests of stakeholders. Interest in the corporate governance practices of modern corporations, particularly in relation to accountability, increased following the high-profile collapses of a number of large corporations during 2001-2002, most of which involved accounting fraud; and then again after the recent financial crisis in 2008. Corporate scandals of various forms have maintained public and political interest in the regulation of corporate governance. In the U.S., these include Enron and MCI Inc. (formerly WorldCom). Their demise is associated with the U.S. federal government passing the Sarbanes-Oxley Act in 2002, intending to restore public confidence in corporate governance. Comparable failures in Australia (HIH, One.Tel) are associated with the eventual passage of the CLERP 9 reforms. Similar corporate failures in other countries stimulated increased regulatory interest (e.g., Parmalat in Italy).

In contemporary business corporations, there are two types of stakeholders; external and internal. The main external stakeholder groups are shareholders, debt holders, trade creditors and suppliers, customers, and communities affected by the corporation's activities. Internal stakeholders include the board of directors, executives, and other employees.

Much of the contemporary interest in corporate governance is concerned with mitigation of the conflicts of interests between stakeholders (Goergen, 2012).In large firms where there is a separation of ownership and management and no controlling shareholder, the principal-agent issue arises between upper-management (the "agent") which may have very different interests, and by definition considerably more information, than shareholders (the "principals"). The danger arises that, rather than overseeing management on behalf of shareholders, the board of directors may become insulated from shareholders and beholden to management (Bebchuk et al 2004). This aspect is particularly present in contemporary public debates and developments in regulatory policy. Ways of mitigating or preventing these conflicts of interests include the processes, customs, policies, laws, and institutions which have an impact on the way a company is controlled. An important theme of governance is the nature and extent of corporate accountability. A related discussion at the macro level focuses on the impact of a corporate governance system on economic efficiency, with a strong emphasis on shareholders' welfare. This has resulted in a literature focussed on economic analysis (see more details at Shleifer and Vishny (1997), Hart (1989), Zelenyuk, and Zheka (2006).

The role that the banks play in any economy cannot be neglected and therefore deserves much attention. However despite of the importance of banking sector in the economy of a country, very little attention has been paid 
to the corporate Governance in banking sector. There are many studies on corporate governance, yet only a few papers focus on banks' corporate governance (e.g.Adams and Mehran, 2005; Caprio et al., 2007; Levine, 2004; Macey and O’Hara, 2003). As discussed by the Macey and O'Hara (2003) that not just the corporate Governance of Bank itself is important but also the other way of looking into the bank is as it plays important part in the governance of the other sort of firms. The importance of the corporate Governance of banks in developed economy as same as that of developing economy therefore much work should be done on the corporate governance of banks as these are the important and major means of managing finances in the country. Two other scholars Shleifer and Vishny (1997), point out in their survey that there has been very little research done on the corporate governance outside the United States except few developed countries as Japan and Germany

For a banking sector of a country the effective corporate governance practices are essential to the proper functioning of the banking sector and economy as a whole. Poor corporate governance may contribute to bank failures and ultimately the whole economy of the country is suffered. The Basel Committee for banking supervision (2006), defines corporate governance as involving

"A set of relationships between a company's management, its board, its shareholders, and other stakeholders. Corporate governance also provides the structure through which the objectives of the company are set, and the means of attaining those objectives and monitoring performance are determined. Good corporate governance should provide proper incentives for the board and management to pursue objectives that are in the interests of the company and shareholders and should facilitate effective monitoring, thereby encouraging firms to use resources more efficiently."

The definition of Corporate Governance given by the Organization for Economic Co-operation and Development (2004) describes corporate governance is a set of relationships between corporate management, the board of directors, shareholders and other stake holders. It also provides the structure through which corporate objectives are set, and the means of accomplishing those objectives and monitoring performance are determined. Shleifer and Vishny (1997) reveal the broader view of corporate governance as the process by which the suppliers of finance control managers to ensure that their capital cannot be misused and they receive a return on their investment. More specifically, corporate governance includes the entire range of arrangements on the basis of which the firm relates to its major financial stakeholders egg creditors and share holders. Another definition by Grundmann and Mulbert (2000) describes corporate governance as encompassing the standards for decision making within a company, the duties of the board members and officers, the internal structure of the firm and the relationship between the corporation and its share holders and other stakeholders.

Levine (2004) has focussed on the importance of corporate governance in banks. His emphasis was on the bank managers to adopt sound governance mechanisms and to allocate capital efficiently and effectively and formation of effective corporate governance principles over the firms they give funds. This is due to the fact that if bank managers give more importance to their own interests rather than the interests of share holders and debt holders then banks will not be able to allocate society's savings efficiently and effectively and thus will not be able to exercise sound corporate governance principles. According to the corporate governance of Lloyds bank, the board of the bank consider that the good governance is about achieving the objective of the group as a whole which involve maximizing shareholder's value over time. It's the very crucial element in the director's mind when applying the principles contained in the combined code on corporate governance issued by the financial reporting council. Therefore the board of directors has to maintain a balance between the interests of shareholders and other stakeholders such as creditors, depositors).

Corporate governance defined in the Cadbury report is "as the system by which companies are directed and controlled". The main focus of the Cadbury report (1992) was on the financial control mechanisms and the responsibility of the board of directors, the auditor and shareholders. It is concerned with structures and the allocation of responsibilities within companies. According to Du plessis and Jean (2005), an effective board is one by which the duties are being performed efficiently imposed by law on the directors and add value to the particular firm in a long run. The board of directors should have a proper understanding of and competence to deal with the emerging issues of the business, and review effectively the challenges and make the performance of the company good, protect the rights of shareholders and make the company financial reporting effectively. This means that directors and managers play very vital role in the corporate governance. Dimsdale and Prevezer (1994) concluded in their research that corporate governance is about the relations between directors, managers and other parties and tells us the way by which the corporations are governed in the UK. According to the research of Mallin et al (2005), corporate governance deals with both the internal aspects of the company such as internal controls and board structure, and external aspects such as the as the relationship with shareholders and stakeholders and the most important of all it tell us the process by which the objectives of the company are set and the ways to achieve those objectives and monitoring the performance.

\subsection{Corporate Governance In Financial Services}

Recent research suggests that corporate governance reforms in the nonfinancial sector may not be appropriate for banks and other financial sector firms (Adams and Mehran, 2003). This is based on the view that no single corporate governance structure is appropriate for all industry sectors, and that the application of governance models to particular industry sectors should take account of the institutional dynamics of the specific industry. Corporate governance in the banking and financial sector differs from that in the non-financial sectors because of the broader risk that banks and financial firms pose to the economy (Eatwelland Taylor2000).As a result, the regulator plays a more active role in establishing standards and rules to make management practices in banks more accountable and efficient. Unlike other firms in the nonfinancial sector, a mismanaged bank may lead to a bank 
run or collapse, which can cause the bank to fail on its various counterparty obligations to other financial institutions and in providing liquidity to other sectors of the economy.

Therefore, the role of the board of directors becomes crucial in balancing the interests of shareholders and other stakeholders (eg., creditors and depositors). Consequently, bank regulators place additional responsibilities on bank boards that often result in detailed regulations regarding their decision-making practices and strategic aims. These additional regulatory responsibilities for management make that banking regulation is a substitute for corporate governance.

According to this view, the regulator represents the public interest, including stakeholders, and can act more efficiently than most stakeholder groups in ensuring that the bank adheres to its regulatory and legal responsibilities.

Corporate Governance is the basics of every financial institution or firm. Good governance leads to prosperity of the industry or firm and poor governance leads to poor performance of the firm and effect the economy as a whole. Banks are very critical elements of the economy and the main function of the bank is to provide finances to the other commercial enterprises so the way the corporate governance works in Bank (financial sector) is different from the other non financial sectors as stated by the two famous scholars Adams and Mehran (2003) in their research that corporate governance rules practised in the non financial sectors are not appropriate for the banking and other financial sector firms. This is based on the view that nosingle corporate governance structure is appropriate for all industry sectors, and that the application of governance models to specific industry should take into account the institutional setup. Similarly Eatwell and Taylor (2000) found that Corporate governance that's is being carried out in banking and financial Sector is different from that in the non-financial sectors because of the greater risk that banks and financial firms pose to the economy. Financial Sectors can be stated as the agents for the economy and are specialist in the buying and selling of the financial contracts and securities at the same time. He gave the detail of the banks as basically banks are the subset of the financial institutions, which are the retailers of the financial securities and deals with the buying and selling of the securities that's why banks are the critical element of the economy and the success and growth of the economy lies in the success of the corporate Governance of banks.

\subsection{Basel Committee for Banking Regulatio}

The function of the bank depends on the adoption of the corporate governance structure effectively. The banking supervision can't function well without sound corporate governance principles. The Basel Committee for banking regulation publish time to time new papers to ensure the implementation of sound corporate governance principles in every bank. There is no doubt that the Basel Committee (2006) has recognized the importance of the role of the banks in an economy and the different failures that originate from the inefficient and poor management of the corporate governance and the need for safeguard for the interests of the shareholders and other stake holders including super visors, Governments and depositors.
According to Basel Committee on banking regulation (1999), the strategies and techniques that are basic to the sound corporate governance include

- the corporate values, codes of conduct

- a well-articulated corporate strategy through which the overall success of the

- Enterprise and the contribution of individuals can be measured

- the clear assignment of responsibilities and decisionmaking authorities including a hierarchy of required approvals from individuals to the board of directors;

- establishment of a mechanism for the interaction and cooperation among the board of directors, senior management and the auditors;

- strong internal control systems, including internal and external audit functions

- Appropriate information flows internally and to the public.

The Basel Committee (2006) underlines the key role of the board of directors and senior management for the safety, soundness of the banks in terms of the corporate governance principles and implementation in a bank. The Basel Committee not only emphasize on the board structure (including size) to promote efficiency and proper strategic direction but also on the appointment of an adequate number of directors that are capable of exercising independent judgment of the views of management, political interests or inappropriate outside interests.

The Basel Committee on Banking Supervision states that the supervisors have keen interests in sound corporate governance principles because the effective management of the business affairs by its board and seniors management leads to the maintenance of an efficient and cost effective supervisory system. To assist supervisors and banking organizations worldwide for the implementation of sound corporate governance practices the guidance paper gives eight high level principles. These guidelines in principle apply to all types of banking organisations. These principles are as follows

1. The members of the board should be qualified for their positions, have a clear understanding of their role in corporate governance and be able to exercise sound judgment about the affairs of the bank

2. The board of directors should approve and oversee the bank's strategic objectives and corporate values that are communicated throughout the banking organisation

3. The board of directors should set and enforce clear lines of responsibility and accountability throughout the organisation

4. The board should ensure that there is appropriate oversight by senior management consistent with board policy

5. The board and senior management should effectively utilise the work conducted by the internal audit function, external auditors and internal control functions

6. The board should ensure that compensation policies and practices are consistent with the bank's corporate culture, long-term objectives and strategy, and control environment.

7. The bank should be governed in a transparent manner 
8. The board and senior management should understand the bank's operational structure, including where the bank operates in jurisdictions, or through structures, that impede transparency

\subsection{Role of Directors}

In the corporate governance framework, bank directors have a number of important responsibilities, including hiring and overseeing the management team, setting major policies and objectives, monitoring compliance with these policies, and participating in the significant decisions within the bank. Thus, directors play a key role in setting the parameters under which management is to operate, and board decisions should have a significant influence on a bank's performance Spong and Sullivan (2007).

In order to achieve good corporate governance rules followed and implemented in a bank sector the role of senior executive and the board is very critical element in governance literature. The rules of the governance in banks can be found but the main responsibility of the board is to implement it accordingly to achieve the proper code of conduct and corporate objectives in a bank. For this purpose there are few factors that need to consider while understanding the role of the board in a corporate world.

According to the Walker (2009), the responsibility of a director(executive or non-executive) and board is to promote the success of the company. Directors must act in good faith and promote the success of the company for the benefit of its members and while practising all this they must have to consider the following six factors

1. the consequences of any decision in the long term;

2. the interests of the company's employees;

3. the need to promote the company's business relationships with suppliers, customers and others;

4. the impact of the company's operations on the community and the environment;

5. the desirability of the company maintaining a reputation for high standards of business conduct; and

6. the need to act fairly between members of the company.

In the Basel Committee Guidance on Corporate Governance for Banks principle 2 states that the board of directors should approve and oversee the bank's strategic objectives and corporate values that are communicated through the banking organisation. The board should ensure senior management implements effective policies to prevent such activities that could diminish the quality of corporate governance e.g. internal lending to officers, employees and board members, preferential treatment for related parties and other favoured entities and conflicts of interests. In order to practice the good corporate governance principles in UK there has been a long debate about good corporate governance practices and how they can be implemented. Moreover there has been different changes and recommendations been made time to time to achieve the good corporate governance environment.

The Cadbury Report's (1992) recommendations for good corporate governance highlighted the importance board conduct and director behaviour and the quality and timing of information for investors. The recommendations encouraged not only firms, but investors as well, to examine the working practices of boards of directors and called for more frequent and clearer disclosures about those working practices. The key ingredient of good corporate governance, the Report recommended, was better reporting of both financial accounting and performance information but also of the working practices of the firm and those boards and committees responsible for the firm (Milner, 2008). Boards should be answerable to company owners, to account properly for their stewardship and to ensure both sound internal control and the ethical health of the organisations. The use of overlycomplex financial products, which thwarted effective supervisory control, and the unethical advancement, at the point of sale, of loans to people with little realistic hope of repaying them shows a lack of basic corporate governance. Mulbert (2000) suggests that indeed supervisors have the prime concern of keeping a bank safe and sound, corporate governance is about business management practices in particular the management decisions dealing with the structure of the organization.

Alchian and Demsetz (1972) discuss that the role of the board in the governance of a bank is a costly activity in terms of time and effort. The contributions that the directors make in the governance of a bank depend on the ability of a bank to attract knowledgeable and thoughtful individuals to the board

A fundamental role of the board is to provide oversight, direction and control but also to challenge where necessary(Ahmed 2009).According to the Independent Evaluation office of IMF (2007), Governance in bank determines how goals are set; how strategies are designed, adopted and implemented; and how results and performance are monitored and evaluated. Good corporate governance should provide a framework and incentives to pursue these activities in an effective and efficient manner, ensuring that organizational units and individuals are held accountable and creating space for stakeholders' views to be considered.

The Bank governance principles in Basel 2 discuss the Board structures, composition and responsibilities of the members of the board. According to the principles the board should be composed of people of good character and integrity and by people of different backgrounds with expertise in areas including law, accounting, and risk management. Hamid (2005) in his speech feels that good corporate governance practices are so important because they help ensure that managers act in the best interest of their shareholders rather than acting solely in their own interests or those of a majority shareholder. Well governed companies are directed by their boards, have mechanisms for protecting minority share holders. His first observation is that boards of directors should become more engaged in the selection of top management. Top management positions should be filled by a transparent process where the board makes the final decision so that the most qualified candidates are chosen.

In the Basel Committee Guidance on Corporate Governance principle 1 states that Board members should be qualified for their positions, have a clear understanding of their role in corporate governance and be able to exercise sound judgment about the affairs of the bank. In the Walker Review he suggested that Good corporate governance overall depends critically on the abilities and experience of individuals and the effectiveness of their 
collaboration in the enterprise. A balance should be maintained between the policies and rules required by the regulator and the ability of the board to take decisions on business strategy so that the members of the board consider to be in the best interests of their shareholders. According to the Bank of America, the board of the bank sets the manner for the highest ethical standards and performance of their management, associates and for the corporation as a whole. The Board strongly believes that good corporate governance practices are important for successful business performance. Their corporate governance practices are designed to align the interests of the Board and management with those of their stockholders and to promote honesty and integrity throughout Bank of America.

\subsection{Risk Management}

One of the very important roles of the board in the bank is management of the risk in the effective corporate governance of that bank. Spong and Sullivan (2007) states in the article that managing risk is very complicated task in any firm. To check whether a firm is performing well in the assessment of the risk is very difficult matter because preferences for risk are an individual matter. Thus, it may not be easy for outsiders to determine if a particular firm is doing well in managing its risk exposure. Banks compared to many other industries, experience an additional layer of supervisory constraints on the options they consider in managing risks Spong and Sullivan (2007).

For a bank to function well in the corporate world one of the most striking factor concluded is its ability to manage risk. The performance of the bank depends on the management of risk. Good management of risk overall leads to the good governance and effective control in the bank. The guidelines on corporate governance for off shore banks given by the LOFSA (2008) suggests that Good corporate governance practice improves safety and soundness through effective risk management and creates the ability to execute strategy and achieve business objectives in a manner that promotes confidence and protects the interest of stakeholders. It is the key responsibility of the board to provide guidance to the senior management and to ensure that a comprehensive risk management and internal control system is functioning well to boost overall the performance of the bank.

The overall performance of a bank is determined by its ability of managing risk and therefore well governed bank have fast and effective means of managing risk. The failure of the risk management leads to the failure of corporate governance of the bank itself. One of the example of the failure of the bank given by Benhamou in his story about Barings Bank due to poor risk management is the Barring bank Plc which was one of the oldest banks of the United Kingdom was declared bankrupt in 26 February 1995. That's why Pyle (1997) in his conference on risk management suggests that the need for the risk management arises from the recent financial disasters in financial and non-financial firms and in governmental agencies. He gave the definition of risk management as the process by which managers satisfy the needs by identifying key risks, obtaining consistent, understandable, operational risk measures, choosing which risk to reduce and which to increase and by what means and establishing procedures to monitor the resulting risk position.

Another view about the risk management in banks is given by Sensarma and Jayadev (2009) in their journal about risk finance that the commercial bank deals with five important categories of risks, viz credit risk, interest rate risk, liquidity risk, solvency risk, and operational risk. Risk management refers to the overall process that a bank follows in identifying the risks to which it is exposed, quantifying those risks and controlling them Also AlTamimi and Al-Mazrooei (2007) wrote in their journal of risk finance that Risk management is the cornerstone of all banking organisations and there is no doubt in the fact that all banks in today's practice re facing large number of risks which may threaten the survival and success of the bank. In short Banking is a business of risk that's why effective risk management in the bank is absolutely required.

In order to fulfil the need of a bank to assess its risk management procedures and to control the overall operations in the bank effectively and efficiently Dedman and Robert-Tissot (2001) in their journal suggest 7 steps involved in the systematic approach of risk management in a bank. These steps are

1. Review loss and claims experience both within the bank and within other banks conducting similar business. Identify at the outset of each transaction the vulnerable areas

2. Review the manner in which the instructions are handled

3. Consider how procedures may be improved in order to reduce risk

4. Operate where possible a system of dual control

5. Consider which staff should bear responsibility for what and how that responsibility would be managed

6. Consider the adoption of standard letters to the client covering important areas

7. Consider specifying the purpose of the advice when drafting letters of engagement so that liability for losses falling outside the parties' purpose can effectively be excluded.

\subsection{Corporate Governance in Lloyd's Bank}

\subsubsection{Introduction}

The bank Lloyd's TSB is leading the UK financial services group and provides a wide range of banking and financial services in UK to personal and corporate customers. The business activities involve retail, commercial and corporate banking, general insurance, and life, pensions and investment provision. These services are offered through a number of well recognized brands involving Lloyds TSB, Cheltenham \& Gloucester, and Scottish Widows. (Lloyd's TSB Company Overview).

Lloyd's TSB has a long history within the banking sector. It was formed originally in 1765 as Lloyds Bank, it merged with the Cheltenham \& Gloucester Building Society in 1995 and later that year, merged with the TSB Group plc to form Lloyds TSB Bank plc. The business got larger in 2000 when this new group took over Scottish Widows. Lloyds TSB has recently grown through a further acquisition. By acquiring HBOS (Halifax/Bank of Scotland) plc, the Lloyds Banking Group has become the 
largest retail bank in the UK. Around half of all people in the UK (30 million) now bank with the Lloyds Banking Group (The Times 100, Lloyd's TSB).

The strategy of the Lloyd's TSB focus on growing the business through developing long-term customer relationships and building customer franchise. The focus on developing their relationships with personal, commercial and corporate customers, whilst developing innovative products that meet the needs of existing customers and attract new customers, is a key driver for income and business growth. This will enable them to achieve their vision of being the best financial services organization in the United Kingdom (Lloyds TSB Strategy).

The corporate responsibility of Lloyd's TSB involves commitment with their stake holders, particularly with the people, customers and the community in which they do the business. Lloyds Banking Group will be one of the biggest UK corporate investors in the community. That investment will include areas such as the Lloyds TSB Foundations, the HBOS Foundation, sponsorship and financial inclusion. The Group's corporate responsibility focus will continue supporting delivery of the business strategy, including responsible lending and support for customers facing difficulties, widening financial inclusion, and delivering substantial community participation (Lloyd's TSB Corporate Responsibility)

\subsubsection{Corporate Governance in Lloyd's Bank}

The governance of the bank depends on the board and its ability to comply with the combine code of corporate governance. The board considers that good governance is vital for achieving the objective of maximising shareholder value over time. This is the top priority in the minds of the directors when applying the principles contained in the combined code on corporate governance issued by the Financial Reporting Council (Lloyds TSB Corporate Governance).However good corporate governance should contribute to better company performance by helping a board discharge its duties in the best interests of shareholders; if it is ignored, the consequence may well be vulnerability or poor performance. Good governance should facilitate efficient, effective and entrepreneurial management that can deliver shareholder value over the longer term. (Financial Reporting Council 2008).

In the Lloyd's Bank, the group is led by a board comprising executive and non-executive directors with wide experience. The appointment of directors is considered by the board and, following the provisions in the articles of association, they must stand for election by the shareholders at the first annual general meeting following their appointment and must retire, and may stand for re-election by the shareholders, at least every three years. The retirement age for the Executive directors is normally 60 as required by their service agreements. Independent non-executive directors are appointed for three-year renewable terms, which may be terminated without notice or payment of compensation. (Lloyds TSB Corporate Governance).

The board meets at least nine times a year. It has a programme designed to enable the directors regularly to review corporate strategy and the operations and results of the businesses and discharge their duties within a framework of prudent and effective controls relating to the assessing and managing of risk. (Lloyds TSB Corporate Governance)

\subsubsection{The Duties of the Board:}

The roles of the chairman, the group chief executive and the board and its governance arrangements, including matters specifically reserved to the board for decision, are reviewed annually. The board has delegated to management the power to make decisions on operational matters, including those relating to credit, liquidity and market risk, within an agreed framework. All directors have access to the services of the company secretary, and independent professional advice is available to the directors at the group's expense, where they judge it necessary to discharge their duties as directors. (Lloyds TSB, Corporate Governance).

The duties of the Board include to take and review decisions on the long -term objectives of the group,to approve the strategies necessary to achieve these objectives and risk inherent in these strategies, to ensure that the board has the appropriate number and quality of directors to fulfill the responsibilities and appointment of committees of the board with terms reference as necessary. In terms of the executive management of the group the board is responsible for establishing and maintaining the appropriate systems to plan and control group operations and risks and to comply with relevant legislation and regulations and also provides regular and sufficient information to the members to enable to discharge its monitoring duties in relation to the matters. (Lloyds TSB Role of the Board).

The performance of the committees and individual directors are evaluated by the board. The internally produced questionnaire are used for this purpose, gives directors the opportunity, through their membership of boards of other companies, in the UK and overseas, to ensure that the group follows best practice. It also enables directors to suggest how the board's procedures may be improved; to assess strengths and weaknesses; and to address its balance of skills, knowledge and experience. The committees, themselves, assess their respective roles, performance and terms of reference and report accordingly to the board. (Lloyds TSB Corporate Governance).

\subsubsection{The Remunertion Committee}

The remuneration committee reviews the performance of the chairman, the deputy chairman, the group chief executive and the other group executive directors, when considering their remuneration arrangements. (Lloyds TSB Corporate Governance).

The committee is appointed by the board and comprises of the Chairman of the company. The appointment of the Chairman is considered independent and as the nonexecutive directors of the company. The chairman of the committee is appointed by the board. In the chairman's temporary absence, one of the other members nominated by the chairman or elected by the other members of the committee will act as chairman. However, the Chairman of the company would not act as chairman of the committee and would not participate in discussions relating to his terms of service, including remuneration. (Lloyd's TSB, Remuneration Committee). 


\subsubsection{The Responsibilities of the Remuneration Committee}

The responsibilities of the remuneration committee is

- To review at least annually, the remuneration policy for those considered by the committee and the Group Chief Executive to be in the top management group, to ensure that members of the executive management are provided with appropriate incentives to encourage them to enhance the performance of the group.

- To determine the terms of service, including remuneration for the Chairman and the Company Secretary of Lloyds TSB Group plc and for any other directors and employee of Lloyds TSB.

- To determine pension arrangements, targets of performance related pay schemes for executive directors and others mentioned above.

- To report on these matters referred by the Chairman or the board at the first convenient board meeting following committee's decision.

- To submit a draft of the remuneration report to the board and review periodically and update its own terms of reference to reflect best practice. (Lloyds TSB, Responsibilities of the Remuneration Committee).

\subsubsection{The Nomination Committee}

The nomination committee reviews the performance of all the directors. The committee report to the board on their deliberations, including the results of these performance evaluations. (Lloyds TSB Corporate Governance).

\subsubsection{The Responsibilities of the Nomination Committee}

The committee is authorised to obtain independent professional advice on any matters within its terms of reference.

- To review regularly the structure, size and composition(including the skills, knowledge and experience) of the board and make recommendations to the board regarding any changes;

- To consider potential candidates for appointment as directors of the company and to make recommendations to the board

- To make recommendations to the board about the reappointment of any non-executive director, reelection of any director of the company by the shareholders, any matters relating to the continuation in office as a director of any director of the company at any time and the appointment of any director of the company to the executive or other office in the company.(Lloyds TSB, Nomination Committee).

\subsubsection{The Audit Committee}

The committee is appointed by the board and comprise of independent non-executive directors. The chairman of the committee is appointed by the board. In the chairman's temporary absence, one of the directors nominated by the chairman or elected by the other members of the committee will act as chairman. (Lloyds TSB, Audit Committee).

\subsubsection{The Responsibilities of the Audit Committee}

The responsibilities of the committee are
- To approve the appointment, reappointment and removal and terms of engagement of the external auditor;

- To discuss with the external auditor the nature and scope of the audit and review the auditors' quality control procedures and steps taken by the auditor to respond to changes in regulatory and other requirements before the audit commences;

- To review the reports prepared by the external auditor, the external auditor's management letter, the internal audit programme, the company's procedures for detecting fraud and resolve any disagreements between management and the external auditors regarding financial reporting;

- To establish procedures for handling the receipt, retention and treatment of complaints received by the company, the confidential submission by employees of the group;

- To review, and challenge where necessary, the actions and judgements of management, in relation to the interim and annual financial statements before submission to the board;

- To report to the board after each meeting.(Lloyds TSB, Responsibilities of the Audit Committee)

\subsection{Corporate Governance in Co Operative Bank}

\subsubsection{Introduction}

The Co operative bank is a part of the Co operative financial services which is the name of the group of businesses came into operation in 2002 that includes other than the Co operative bank the Co-operative Insurance, the Co-operative Investments, including smile and Britannia. The Co operative group has 6.5 million customers(Co operate Financial Services, About Us).

The Co-operative Bank is the only UK high street bank with a clear Ethical Policy that is based on the views of its customers. The Policy sets out the businesses that the Bank will and will not provide banking services and investment of funds to. The Co-operative Bank offers a wide range of banking products from mortgages and loans to current accounts, credit cards and saving and investment products. It is also consistently rated highly in independent surveys for excellent customer service and has won many recent awards for a variety of products.(Cooperative Financial Services, Our Business).The purpose of the Co-operative bank is to be a pioneering business delivering sustainable financial services for members and society (Co-operative Financial Services, Our purpose).

The Co-operative Financial Services committed to leading the way on ethical, environmental and community matters. Both The Co-operative Insurance and The Cooperative Bank have unique ethical policies setting out the way they do business which have been developed in full consultation with customers (Co operate Financial Services, About Us).

\subsubsection{Duty of the Board:}

In the Co-operative financial services group, the individual boards act as the overall governing bodies for the Co-operative financial services as a whole and for respective subsidiaries. The individual Boards have a 
common composition. The Boards are responsible for the overall governance including ensuring senior management establish and maintain adequate systems of risk management and that the level of capital held is consistent with the risk profile of the businesses. The Board comprises of 13 nonexecutive Directors and 4 executive Directors, including 4 Independent Professional non -executive Directors as defined under the combined code. The division of responsibilities between the Chair of the Board (a nonexecutive Director) and the Chief executive is clearly defined. (Co-operative Financial Services, Corporate Governance)

\subsubsection{Duties of the Committees}

The Co-operative financial services board clearly delegates activities to its sub-committees in order to give specific focus and attention to a number of key governance activities. Risk Management is a central theme of each of the Board sub-committees and this structure, and is designed to give the Board a joined up view of strategy, capital and risk. Within this structure the Risk Management Committee (RMC), the Risk Management Working Group (RMWG), The Co-operative Financial Services Exposures Committee and the Chief Executive have specific responsibilities in relation to credit risk. (Co-Operative Financial Services, Activities Delegated to Committees)

\subsubsection{Risk Management Committee (RMC):}

The duty of this to focus focuses in depth on risk management activity. It reviews and challenges risk management information and processes, approving risk policy and credit models and setting standards. This committee is the most senior forum within the organization. (CoOperative Financial Services, Board Committee Summary)

\subsubsection{Risk Management Working Group (RMWG):}

The duty of this committee is to provide input into, and approval of, the development of CFS risk management activities and standards. This includes approving all material aspects of the Bank's rating and estimation process in relation to the IRB approach. This committee operates on an interim basis on a monthly cycle. (CoOperative Financial Services, Board Committee Summary)

\subsubsection{Exposures Committee}

The duty of this committee is to ensure that nonexecutive directors are actively involved in major credit decisions (including sanctioning large counterparty transactions) and monitoring large exposures. (CoOperative Financial Services, Board Committee Summary)

\subsubsection{Audit and Regulatory Compliance Committee (ARCC)}

The responsibility of this committee is to provide provides independent oversight in relation to financial reporting; internal control and risk management; regulatory compliance; external audit and internal audit. (CoOperative Financial Services, Board Committee Summary)

\subsubsection{Executive Committee}

The responsibility of this committee is to manage the business in line with the Board Risk Appetite Statement (Risk Appetite) using a Board delegated risk mandate. It also maintains oversight of risk management processes and management information through regular input from the individual Sector Management Groups. (Co-Operative Financial Services, Board Committee Summary).

\subsubsection{Remuneration and Appointments Committee}

The responsibility of this Committee is to determine remuneration and employment policy oversee contractual arrangements, review salaries, and approve incentive schemes and any payments made under such schemes and recommend appointments to the Boards. In respect of Directors, the Committee makes recommendations to members in General Meetings for decision. (Co-Operative Financial Services, Board Committee Summary)

\section{Research Methodology}

\subsection{Case Study Approach}

To study the corporate governance principles and policies in the banks the methodology which is adopted in this research is case study approach. Yin (1984) gives the definition of the case study in the research as the method of case study analysis in the research refers to a group of methods which emphasize on qualitative analysis. Gable (1994) describes case study as in the case study the data are collected from the small number of organizations through different methods such as participant-observation, in-depth interviews, and longitudinal studies.

\subsection{Aim of Case Study Approach}

The aim of case study approach is that it seeks to understand the problem which is being investigated. It provides the opportunity to ask penetrating questions and to capture the richness of organizational behaviour, but the conclusions drawn may be specific to the particular organizations studied and may not be generalizable. Soy (1997) explains case studies as it generally involve multiple sources of data, may include multiple cases within a study, and produce large amounts of data for analysis because of which case studies are complex. Researchers from many disciplines use the case study method to build upon theory, to produce new theory, to dispute or challenge theory, to explain a situation, to provide a basis to apply solutions to situations, to explore, or to describe an object or phenomenon Yin (1984) suggests that case studies are appropriate where the objective is to study contemporary events, and where it is not necessary to control behavioural events or variable. Saunders, Lewis and Thornhill (2007) states in their book of Research Methods For Business Students that the case study approach in a research has the ability to generate answers to the question 'why?' as well as the 'what?' and 'how?' questions with particularly focus on 'why?' in the research. Because of this reason the case study method is most often used in explanatory and exploratory research. The techniques for the collection of data are can be used in combination with the other research methods and techniques(Saunders, Lewis and Thornhill, 2007).

\subsection{The Benefits of the Case Study Approach}

The usefulness of the case study approach is given by Yin (2003) describes as case study research is an essential 
form of social science inquiry. This method is used by the investigators or researcher desire or forced by circumstances. It allows the researcher or investigators to define research topics broadly not narrowly, to cover contextual or complex multivariate conditions and not just isolate variables and also to rely on multiple and not singular sources of evidence. Soy (1997) further discuss the advantages of the case study method are its applicability to real-life, contemporary, human situations and its public accessibility through written reports. Case study results relate directly to the common readers everyday experience and facilitate an understanding of complex real-life situations. Further the strengths of the case studies used in the research are given by Gummesson (1991) states that case study approach in research enables the researcher to gain a holistic view of a certain phenomenon or series of events and can provide a round picture since many sources of evidence can be used. Another advantage of the case study given by Hartley (1994) is that it can be useful in capturing the emergent and immanent properties of life in organizations and the ebb and flow of organizational activity, especially where it is changing very fast. Case studies also allow generalizations as that result of findings using multiple cases can lead to some form of replication. Yin (2003) describes the applicability of the case study method by saying that numerous researcher and students continue to want or need to do case studies on various diverse topics including business and organizational issues, education, child and youth development, family studies, international affairs, technology development and research on social problems.

The purpose of using case study approach in this research is because of the nature of the case study approach as explanatory and exploratory. The concept of corporate governance in banking organization is an explanatory concept and can be better understand by using the case study approach in the research. The corporate governance issues and principles that are practiced the Lloyd's bank and in the Co-operative bank needed to be explored by using the case study approach the different policies and principles that are practiced in the bank are identified and discussed in this research. Further the role of the directors in implementing the sound corporate governance principles and policies in the bank their responsibilities and the responsibilities of the different committees that are formulate in the bank are explored and discussed in the research.

The methods that can be applied and used in the case study approach are various and one of which is also in depth interviews. Due to the qualitative nature of the research topic and limited information carried by the members of the Lloyd's bank and Co-operative bank it was not possible to conduct in depth interviews with the staff of the both banks. Mostly the employees working in both banks have limited information about the corporate governance issues that are prevailing in these banks. The staff has information just required by them to carry their activities related to their post in the bank. That's why mostly that data that is collected is from the websites of these banks, which provide the more systematic and detailed information about the corporate governance policies and principles practicing in the Lloyd's and as well as in the Co-operative bank. The Lloyd's bank and the Co-operative bank being different from one another in terms of their services offered to the general public was an interesting study and provide detailed policies and principles of the corporate governance in these banks. The corporate governance policies that are prevailing in these banks are compared with the sound corporate governance principles and techniques mentioned earlier in this study.

\section{Results and Discussions}

The main objective and aim of this research paper is to find out the best practices of corporate governance issues and policies in a bank to achieve the objective of the organisation. For this purpose the data about the corporate governance policies and principles in the Lloyd's and Cooperative bank are gathered by case study analysis in both the banks. Majority of the data about the corporate governance and the way it is being implemented in both these banks are found from the websites' of these banks. The concept of corporate governance has been explored by different researchers and scholars in different times including Macey and O’Hara (2003), Shleifer and Vishny (1997), Grundmann and Mulbert (2000), Levine (2004), Du plessis and Jean (2005), Dimsdale and Prevezer (1994),Mallin et al (2005) discussing the definition of the corporate governance with terms of the shareholders and stakeholders and the most important of all it tell us the process by which the objectives of the company are set and the ways to achieve those objectives and monitoring the performance.

In the Lloyd's Bank the corporate governance statement is well defined and clear by stating that the board is familiar with the policy of corporate governance and by applying the sound corporate governance policy can lead them to achieve the objective by maximising shareholder value over time. The directors consider this as a priority when applying the principles contain in the combine code for corporate governance by the Financial Reporting Council. This statement of the Lloyd's bank states the objective of the firm and the supervisor concern for the achievement of the objective of the firm. In the Literature Review Hamid (2005) discussed good governance is very important because it help to ensure that the managers act in the best interests of their shareholders rather than acting solely in their own interests or those of a majority shareholder. Whereas the Data given by the corporate governance in the Co-operative bank is very limited and doesn't clearly provide the understanding of the corporate governance code applied in the bank.

Another important discovery that has been find out in the research is that the corporate governance policies in the financial sector are different from the non-financial sector. Various researchers Adams and Mehran (2003) and Eatwell and Taylor (2000) found that Corporate governance that's is being carried out in banking and financial Sector is different from that in the non-financial sectors because of the greater risk that banks and financial firms pose to the economy.

The success of the bank depends upon the policies and procedures of the corporate governance that is implemented in the bank. Good governance leads to the success of the firm and on the other hand poor governance and misconduct of the banking regulations leads to the 
failure of the bank. So from the study of the banks and corporate governance issues and policies the first outcome is the ways of handling the corporate governance policies in a bank leads to the success and failure of the bank and ultimately to the whole economy of the country. For this purpose it is very important to find out the best practice or the sound practices of corporate culture in the bank so that the policies can be applied in the similar way in the bank to achieve the goal of the organisation. It has been found that Basel Committee (2006) has recognised this need of analysing the corporate governance policies in the bank and has published time to time new reports to protect and safeguard the interests of the shareholders and other stake holders including super visors, Governments and depositors. There are different techniques that are important in implementing the sound corporate governance in a bank. The guidelines about the techniques are given by the Basel committee for banking regulation (1999) and are discussed in the thesis. To guide in terms of the role of the board in the implementation of these techniques and corporate governance policies in the bank the Basel committee (2006) underlines the key role of the board of directors and senior management for the safety, soundness of the banks in terms of the corporate governance principles and implementation in a bank. Further for the guidance of supervisors and managers in terms of the banking regulations and corporate issues Basel committee has given the eight high level principles to assist the supervisors and managers which are also highlighted in this thesis.

The corporate governance of a bank is a complex topic and needs thorough study of the policies and procedures that are practiced in the bank. As discussed by various researchers and scholars that the role of the board in terms of the corporate governance policies and to implement these policies is of much importance in the research and is the main theme of this study.

The Co-operative financial services discuss the role of the board is to assign clearly the responsibilities and tasks to their sub committees in order to give focus and attention to a number of key governing activities. However in the Basel committee guidance for banking supervision principle 3 and 4 states that the board of directors should set and enforce clear lines of responsibility and should ensure there is proper oversight by the management throughout the organisation.

To review the corporate strategy and the operations and results of the businesses the board of the Lloyd's bank meets at least nine times a year. The duties of the board in the Lloyd's bank include to take decisions on the planning of the firm and to adopt an appropriate strategy to achieve those objectives of the firm and meanwhile also the risk factor in these strategies, the other duties include the management of the staff and also to view and review the performance and fulfilment of the responsibilities. For the effective management in various operations in the bank there are different committees and have different responsibilities to perform in the bank. The performances of these committees are evaluated by the board. The board decides which committee is performing good or which one needs further improvement through internal questionnaire the board finds the strengths and weaknesses in the management of the committees and performance of the committee. The different committees that are responsible for the different duties are remuneration committee, nomination committee, audit committee. These committees perform various tasks in the bank to make remuneration policy after evaluation of the directors performance, the appointment, reappointment of the directors and to make an audit review and other arrangements for the auditor these committee make the report for the board for the meeting.

The board of the Co-operative Bank comprises of 13 non-executive directors and 4 executive directors including 4 independent professional non-executive directors and is clearly define by the code. For the governance of matters inside the bank there are different committees to look after the different issue in the banking system. The committees and their responsibilities are Risk Management Committee (RMC) responsible for the risk management policy in the bank and is the most senior forum in the organisation. Risk Management Working Group (RMWG) is responsible for the risk management activities and standards and provide input for their approval. Exposures Committee is responsible for ensuring that non-executive directors are actively involved in major credit decisions, Audit and Regulatory Compliance Committee is responsible for providing oversight in relation to financial reporting, internal control and risk management and external and internal audit. Executive Committee is responsible for the management of the risk related to the board. Remuneration and Appointments Committee is responsible for determining the remuneration and appointment policy, salaries review etc.

Another very important factor that is discussed in the Co-operative financial services that the management of the risk associated with the bank operations is the duty and consider as the central theme of each of the sub committee, and is designed to give the Board a joined up view of strategy, capital and risk. Considering the importance of the risk management in the banking operations various scholars and researchers Spong and Sullivan (2007), LOFSA (2008), Pyle (1997), Sensarma and Jayadev (2009), Tamimi and Al-Mazrooei (2007) wrote about the importance of risk management in banking and concluding that risk management is very vital for today's system of banking because all banks are suffering from high level of risks and by managing the risk effectively can lead that bank for its survival and growth. The 7 steps of the effective risk management by Robert-Tissot (2001) gives the idea and the concept about risk and how it can by identified and controlled. The various committees in the Co operative financial services are responsible for managing risk are Risk Management Committee (RMC), Risk Management Working Group (RMWG). The establishment of the separate Committee for the management of the risk being critical element in the bank is also discussed in the Walker Review for the Corporate Governance in UK and other financial entities where the Recommendation 23 states that The board should establish a board risk committee separately from the audit committee with responsibility for oversight and advice to the board on the current risk exposures of the entity and future risk strategy. The Co -operative bank fully comply with this recommendation but the Lloyd's bank doesn't comply because of the insufficient information given about the risk management and also the 
bank doesn't establish a separate committee for the management and overseeing the risk.

\section{Conclusion}

Corporate Governance deals with all those issues arise in the banks that are needed for the smooth running and proper planning for the operations of the bank. The study has explored all the aspects of corporate governance in a bank and how it is related to the best practice guide given by the Basel committee for banking regulation. The study of the corporate governance of the Lloyd's bank and the Co-operative bank follow a case study approach with the special emphasis on the role of the board in the implementation of the corporate governance principles in the bank. The study gives us the answer of the question what is corporate governance? How it is in the banks Lloyd's and the Co-operative bank? What does the role of the directors in the corporate governance framework?

Corporate Governance from this study is concluded as the base of every successful bank or firm. The success and failure of every financial institution depends on the implementation of the corporate governance policies and principles. However there are various guidelines given by the Basel committee for banking regulation for the guidance of the bank managers and directors. By analyzing the Basel committee guidance for banking regulation the board should act in the best interests of the company's shareholders rather than acting on their own behalf. The effective management of the business affairs by the board leads to the effective and efficient internal supervisory control.

Another very important factor in the effective corporate governance is the risk management. Many writers and scholars discuss the management of risk as very important and critical element in the business and now a days the environment in which the banks are operation is highly under high risk that's why effective risk management is the duty of the directors and the board.

The corporate governance of the Lloyd's and Cooperative bank is clearly stated in the websites of these banks with a clear explanation of the company policies and rules. The management and responsibility of the board and directors is further assigned to its sub committees so that the affairs of the bank are managed properly with full attention and focus given to each matter. The responsibilities of the committees are discussed and the report is given after the evaluation so that the gap can be found out for improvement and for the evaluation of the performance of the committee. One of the very important factors discussed above is the management of the bank's risk and by organizing a separate committee in the bank; the risk factor can be managed and controlled effectively as discussed by the Walker Review. However the Cooperative bank fully comply with this review of the walker however the Lloyd's bank hasn't organized a separate committee for the management of risk associated with the business affairs and decisions.

Thus for a bank to operate successfully in the corporate world the corporate governance policies implemented is very important and the role of the board in implementing these policies and taking decisions in the day to day operations of the business and considering the risk factors associated with these decisions. By managing these factors effectively the banks and the firm can maintain its stability and success in the corporate world and ignoring any of the above factors can lead to its failure.

\section{References}

[1] Adam, R and Mehran (2003), Is Corporate Governance Different for Bank Holding Companies, Federal Reserve Bank of New York Economic Policy Review, Vol:9, pp: 123-141.

[2] Adams, R.B., Mehran, H., 2005. Corporate performance, board structure and its determinants in the banking industry. Working Paper, SSRN.

[3] Al-Tamimi, H.H and Al-Mazrooei, F.M (2007) Banks Risk Management: A Comparison Study of UAE National and Foreign Banks, Journal of Risk Finance Vol.8, No.4, pp. 394-396.

[4] Anderson, R (2000) Researching Risk Issues in the $21^{\text {st }}$ Century, Balance sheet journal Vol.8, No.3, pp.40-42.

[5] Agoraki et all (2009), "The Effect of Board Size and Composition on Bank Efficiency”, MPRA paper No 18548.

[6] Alchian, A.A and Demsetz, H (1972), "Production, Information Costs and Economic Organization” American Economic Review

[7] Benhamou, E Barings Bank Risk Management Disaster, Swaps Strategy, London, FICC, Goldman Sachs International.

[8] Basel Committee on Banking supervision, "Enhancing Corporate Governance for Banking Organization”.

[9] Basel Committee on Banking supervision, (1999), Enhancing Corporate Governance for Banking Organization, Bank for International Settlements.

[10] Basel Committee on Banking supervision,(2006), Enhancing Corporate Governance for Banking Organization.

[11] Bank Governance Principles and Basel 2, A Best Practice Guide, B11 Compliance.

[12] Bank of America Corp (2009), Notice of 2009 Annual Meeting of Stockholders, Bank of America Corporate Centre Charlotte, North Carolina 28255.

[13] Basel Committee Guidance on Corporate Governance for Banks, Eurasian Corporate Governance Roundtable, Task Force on Corporate Governance of Banks in Eurasia.

[14] Bebchuk, A, Fried, Pay Without Performance - the Unfulfilled Promise of Executive Compensation, Harvard University Press 2004, 15-17.

[15] Borio, C, G Toniolo and P Clement (eds) (2008): Past and future of central bank cooperation, Cambridge-New York: Cambridge University Press.

[16] Cadbury. A (1992) Report of the Committee on the Financial Aspects of Corporate Governance, London, Gee and Co Ltd.

[17] Caprio, G., Laeven, L., Levine, R., 2007. Governance and banks valuations. Journal of Financial Intermediation 16, 584-617.

[18] Cincanelli P., Reyes-Gonzalez J.A. (2000). Corporate Governance in Banking: Conceptual Framework, EFMA Conference, Athens.

[19] Co -operative Financial Services About US, [available at http://www.cooperativebank.co.uk/servlet/Satellite?c=Page\&cid=116652449517 4\&pagename=Corp\%2FPage\%2FtplCorp accessed on $27^{\text {th }}$ Feb, 2010].

[20] Co-operative Financial Services Our Business, The Co-operative Bank [available at http://www.co-

operativebank.co.uk/servlet/Satellite?c=Page\&cid=116945073336 9\&pagename=Corp\%2FPage $\% 2$ FtplCorp accessed on $21^{\text {st }}$ Feb, 2010].

[21] Co-operative Financial Services, Our Purpose [available at http://www.co-

operativebank.co.uk/servlet/Satellite?c=Page\&cid=116945073316 6\&pagename=Corp\%2FPage $\% 2$ FtplCorp accessed on $21^{\text {st }}$ Feb,2010].

[22] Co-operative Financial Services, Corporate Governance, Role of the Board [available at

http://www.co-

operativebank.co.uk/servlet/Satellite?c=Page\&cid=117005387294 8\&pagename=Corp\%2FPage\%2FtplCorp accessed on $17^{\text {th }}$ Jan, 2010].

[23] Co-operative Financial Services, Corporate Governance”, Activities Delegated to Committees [available at http://www.co- 
operativebank.co.uk/servlet/Satellite?c=Page\&cid=117005387294 8\&pagename $=$ Corp $\% 2$ FPage $\% 2 F t p l C o r p$ accessed on $17^{\text {th }}$ Jan, 2010].

[24] Co-operative Financial Services, "Corporate Governance”, Board Committee Summary [available at

http://www.co-

operativebank.co.uk/servlet/Satellite?c=Page\&cid=117005387294 8\&pagename=Corp\%2FPage\%2FtplCorp accessed on $17^{\text {th }}$ Jan, 2010].

[25] Dims dale, N and Prevezer, (1994) "Capital markets and corporate governance"Clarendon Press Oxford.

[26] Du Plessis, J.J;Jean, J (2005) Principles of Contemporary Corporate Governance, Cambridge university press

[27] Dedman, R and Robert-Tissot, S (2001) Risk Management Where Bank Fails, Journal of Balance sheet,Vol. 9, No. 2, pp. 16-17.

[28] Eatwell,J and Taylor (2000),Global Finance at Risk, pp.21-27.

[29] Financial Reporting Council FRC (2008), The Combined Code On Corporate Governance June 2008,FRC Publications.

[30] Financial Reporting Council FRC (2014), The UK Corporate Governance Code September 2014, FRC Publications

[31] Gable, G.G (1994) Integrating Case Study and Survey Research Methods: An example in information systems, European Journal in Information systems Vol.3, No.2, pp. 112-116.

[32] Goergen, Marc, International Corporate Governance, (Prentice Hall 2012).

[33] Gummesson, E (1991) Qualitative method in Management Research, Sage publication,California,pp.83-150 quoted in Mohd Noor, K.B (2008) Case Study:A Strategic Research Methodology, American Journal Of Applied Science, Vol.5,No.11,pp.1602-1603

[34] Grundmann, S and Mulbert, P.O (2000), “Corporate Governance: European Perspectives”, International and Comparative Corporate Law Journal.

[35] Gup B.E. [ed.] (2007). Corporate governance in banking. A Global Perspective, Edward Elgar, Cheltenham-Northampton.

[36] Hamid, J (2005), Corporate Governance and Banking Reform In China, International Finance Corporation at China International Finance Development Forum

[37] Hart, O (1989). "An Economist's Perspective on the Theory of the Firm," Columbia Law Review, 89(7), pp. 1757-1774.

[38] Hartley, J (1994) Case Studies in Organisational Research in Casell and Symon, Qualitative Methods in Organisational Research, Sage Publication, London quoted in Mohd Noor, K.B (2008) Case Study:A Strategic Research Methodology, American Journal Of Applied Science, Vol.5, No. 11, pp. 1602-1603

[39] Hemraj, M.B (2002) Preventing Corporate Failure: the Cadbury Committee's Corporate Governance Report, Journal of Finance Crime, Vol.10, No.2, pp. 141-145.

[40] Independent Evaluation Office, (2007) Aspects of IMF Corporate Governance -Including The Rule of The Board”, Issues papr for an Evaluation by the Independent Evaluation Office (IEO).

[41] James, H (2012): Making the European Monetary Union: the role of the Committee of Central Bank Governors and the origins of the European Central Bank, Cambridge-London: The Belknap Press of Harvard University Press.

[42] Lefort, D (ed) (2009): "Bank for International Settlements (BIS), Basel, Switzerland", in International Encyclopaedia of Laws, Alphen Rijn: Kluwer Law International.

[43] Levine, R., 2004. The corporate governance of the banks: A concise discussion of concepts and evidence. Working Paper, World Bank Policy Research.

[44] Llewellyn D.T. (2008). "An analysis of the causes of the recent banking crises”, The European Journal of Finance.

[45] Lloyd's banking group corporate governance [available at http://www.lloydsbankinggroup.com/about_us/corporate_governa nce.asp Accessed March 19, 2009].

[46] Lloyds TSB, "Corporate Governance” available at http://www.lloydsbankinggroup.com/about_us/corporate_governa nce.asp accessed on 13th Jan, 2010.

[47] Lloyds TSB, "Role Of The Board” available at http://www.investorrelations.lloydstsb.com/media/pdf_irmc/gr/cor p_resp/Role_LTSB_Board.pdf accessed on 14th Dec, 2010.

[48] Lloyd's TSB, "Remuneration Committee" available at http://www.investorrelations.lloydstsb.com/media/pdf_irmc/gr/cor p_resp/LTSB_Remuneration_Committee_May2008.pdf accessed on 1st Jan,2010.

[49] Lloyds TSB, "Responsibilities of the Remuneration Committee" available at http://www.investorrelations.lloydstsb.com/media/pdf irmc/gr/cor p_resp/LTSB_Remuneration_Committee_May2008.pdf accessed on 10 Jan, 2010.

[50] Lloyds TSB, "Nomination Committee" available at http://www.investorrelations.lloydstsb.com/media/pdf_irmc/gr/cor p_resp/LTSB_Nomination_Committee_May2008.pdf accessed on $11^{\text {th }}$ Jan, 2010.

[51] Lloyds TSB, “Audit Committee” available at http://www.investorrelations.lloydstsb.com/media/pdf_irmc/gr/cor p_resp/LTSB_Audit_Committee_Sept2008.pdf accessed on $11^{\text {th }}$ Jan, 2010

[52] Lloyds TSB, "The Responsibilities of the Audit Committee" available at

http://www.investorrelations.lloydstsb.com/media/pdf_irmc/gr/cor p_resp/LTSB_Audit_Committee_Sept2008.pdf accessed on $11^{\text {th }}$ Jan, 2010

[53] Lloyd's TSB, Corporate Responsibility [available at http://www.lloydsbankinggroup.com/about_us/corporate_responsi bility.asp accessed on $21^{\text {st }}$ Feb, 2010].

[54] Lloyd's TSB, Company Overview, Our Strategy [available at http://www.investorrelations.lloydstsb.com/gr/overview.asp accessed on $18^{\text {th }}$ Feb, 2010].

[55] Lloyds TSB, Company Overview,[available at http://www.investorrelations.lloydstsb.com/gr/overview.asp accessed on $21^{\text {st }}$ Feb, 2010].

[56] Labuan Offshore Financial Services Authority (2008), Guidelines on Corporate Governance for Offshore Banks, Labuan Offshore financial services authority Malaysia.

[57] Mulbert, P.O (2009), Corporate Governance of Banks, ECGI Working Paper Series In Law, Law Working Paper No 130.

[58] Macey and O’Hara, (2003) The Corporate Governance of Banks, Federal Reserve Bank of New York Economic Policy Review, pp. 91-107.

[59] Mallin, C Mulleneux (2005), The financial sector and corporate governance the UK case, Corporate governance an international review, Vol. 13 No. 4, pp. 532-47.

[60] Mohd Noor, K.B (2008) Case Study:A Strategic Research Methodology, American Journal Of Applied Sciences [available at http://findarticles.com/p/articles/mi_7109/is_11_5/ai_n28551353/ accessed on $4^{\text {th }}$ March,2010].

[61] Milner, M. (2008) Examining the Authorship of Annual Reports: Issues for Corporate Governance? BAA Conference cited in Ahmed. A(2009) Global Financial Crisis: An accounting Perspective,BAA conference paper.

[62] Organisation for Economic Co-operation and Development (2004) OECD Principles of Corporate Governance.

[63] Pyle, D.H (1997) Bank Risk Management: Theory, Conference on Risk Management and Regulation in Banking, Jerusalem, 17-19 May, UC BERKELEY, Research Programme in Finance working paper RPF-272, pp 2-6.

[64] Shleifer, A and Vishny, R (1997). "A Survey of Corporate Governance," Journal of Finance, 52(2), pp, 737-783.

[65] Soy, S.K (1997) The Case Study as a Research Method,[available at http://www.ischool.utexas.edu/ ssoy/usesusers/l391d1b.htm accessed on $28^{\text {th }}$ Feb, 2010].

[66] Spong, K.R and Sullivan, R.J (2007), Corporate Governance and Bank Performance, Federal Reserve Bank of Kansas.

[67] Santomero, A.M (1997) Commercial Bank Risk Management: An analysis of the process, Conference on Risk Management in Banking,13-15 October, Wharton Financial Institutions Centre.

[68] Sensarma, R and Jayadev, M (2009) Are Bank Stocks Sensitive to Risk Management? Journal of Risk Finance Vol. 10, No.1, pp.7-9.

[69] Toniolo, G with the assistance of P Clement (2005): Central bank cooperation at the Bank for International Settlements, 1930-1973, Cambridge-New York: Cambridge University Press.

[70] The Times 100, Lloyd's TSB, Positive About Disability,[available athttp://www.thetimes100.co.uk/case-study--positive-aboutdisability--99-357-1.phpaccessed on 15Feb, 2010].

[71] Walker, D (2009), “A Review of Corporate Governance of UK Banks and Other Financial Industry Entities "Final Recommendations.

[72] Yin, R.K (1984) Case Study Research: Design and Methods. Sage Publications, Beverly Hills, California.

[73] Yin, R.K(2003) Applications of Case Study Research, Applied Social Research Method Series Vol. 34,2 ${ }^{\text {nd }}$ Edition,Sage Publications, Thousand Oaks, California. 